\title{
Modeling and Relative Research of Solar Photovoltaic Array Topologies Under Partial Shading Conditions
}

\author{
V. Bala Raju, Ch. Chengaiah
}

\begin{abstract}
The electrical power generation from solar photo voltaic arrays increases by reducing partial shading effect due to the deposition of dust in modules, shadow of nearby buildings, cloud coverage leads to mismatching power losses. This paper gives the detailed analysis of modeling, simulation and performance analysis of different $4 x 4$ size $P V$ array topologies under different irradiance levels and to extract output power of panels maximum by reducing the mismatching power losses. For this analysis, a comparative study of six PV array topologies are Series, Parallel, Series-Parallel, Total-Cross-Tied, Bridge Linked and Honey-Comb are considered under various shading conditions such as one module shading, one string shading, zigzag type partial shading and total PV array partially shaded cases. The performance of above six topologies are compare with mismatching power losses and fill-factor. For designing and simulation of different $P V$ array configurations/topologies in MaTLab/Simulink, the LG Electronics LG215P1W PV module parameters are used in all $P V$ modules.
\end{abstract}

Keywords- Solar PV cell, PV array Topologies, irradiance levels, shading effect, mismatching losses, fill-factor.

\section{INTRODUCTION}

In future, electrical power from renewable energy sources increasesespecially solar and wind power systems. Solar photovoltaic systems has more advantages compare to other energy systems and play a major role in renewable sector for power generation. Worldwide the research is going on in the area of Solar PV system for improving its conversion efficiency and also reducing the cost of panels. The efficiency of pv module is less approximately $22-30 \%$ only at standard temperature conditions.Duetoshadingproblem, theefficiencywillbedecreas ed gradually and also it leads to shutdown the entire PV plant. Solar PV systems consists of series - parallel connected modules form PV arrays and to get required voltage, current and output power. For high currents and high voltages are obtained fromPV modules connected in parallel and series respectively altogether to improve the system output power. Normally the PV arrays are exposed to sun direction, under high irradiance the PV modules deliver maximum power. But, due to low irradiance, high temperature and partial shading the Solar PV arrays delivering low output power.[1-3]. Due to Partial shading effect where there is no exposure to sunlight, the arrays output are reduced and also decreases life-span of PV modules[4]. Partial shading caused by the deposition of dust

Revised Manuscript Received on April 12, 2019.

V. BalaRaju,Research Scholar, Dept. of EEE, SVUCE, SV University, Tirupati, A.P, India. (vbrajuu @ gmail.com)

Dr. Ch. Chengaiah,Professor, Dept. of EEE, SVUCE, SV University, Tirupati, A.P, India in modules, shadowing of trees and buildings near to the PV arrays etc., that results output power from arrays are reduced gradually to zero level leads to shut-down of entire PV system [5]-[6]. The power loss occurs in a pv system due to shading effect depends on the shading pattern and array interconnection topologies but notdependonshadingarea. A shadowed pv module behaves as a load and the solar cells in a module will heat up and develop a hot spot in pv modules and these hot spots can damage the pv cells and modules, and leads to long-term decrease in annual system performance of the pv system. The bypass diodes also connected across cells for reducing the effect of shadows. The mismatching power loss can be minimized with bypass diodes connected in parallel to modules. The mismatching power losses occurs in a pv arrays due to partial shading effects are reduced in different topologies i.e., Series(S), Parallel(P), Series-Parallel(SP),Bridge-Linked(BL),TotalCross-Tied(TCT), Honey-Comb(HC) type of array topologies [7]-[10]. By using TCT topology, the lifespan of the pv system increases by $30 \%$ which have been outlined in the literature [11].

This research paper is organized as follows: The mathematical modeling of solar PV cell, module and array described in section-2; Modeling and simulation of different topologies for various shading cases by considering different irradiance levels are presented in Section 3; the comparative and performanceanalysisofarraytopologies, and finally results and discussionsarepresentedinsection 4;conclusionsaregiveninsection5.

\section{SYSTEMDESIGN}

\subsection{Modeling of Photovoltaic Cell, Module and Array}

The solar cell is semiconductor device, it converts the light energy to the electrical energy. The solar module poweroutput depends on irradiance level of sunlight and ambient temperature. Solar modules are connected in series / parallel are depends on output voltage/current requirements. In uniform illumination condition, the array output power is equal to the all pv modules output power.The solar cell electrical energy conversion as shown in figure-1 (a \& b).PV celloutput voltage and maximum power generation is only $0.5 \mathrm{~V}$ and 1 to $5 \mathrm{~W}$ respectively because of the limitation of the process. The formation of PV module is by connecting several cells in series, and the array is formed by modules connected in seriesparallel in order to satisfy the 
high-voltage and high-power supply requirements. The total output power from the PV module depends on the solar irradiation $\left(\mathrm{W} / \mathrm{m}^{2}\right)$ and temperature $\left({ }^{\circ} \mathrm{C}\right)$.

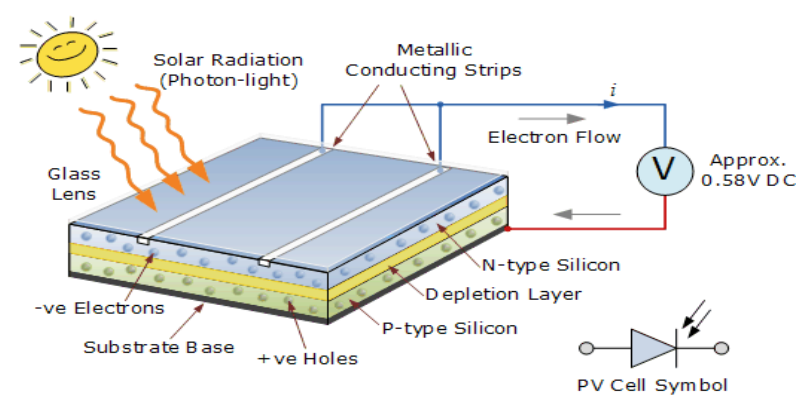

(b)

Figure-1(b) shows the PV Cell, module and solar farm. Connection of cells form a solar module or panel, group of modules in series form an array and many arrays make a solar farm.

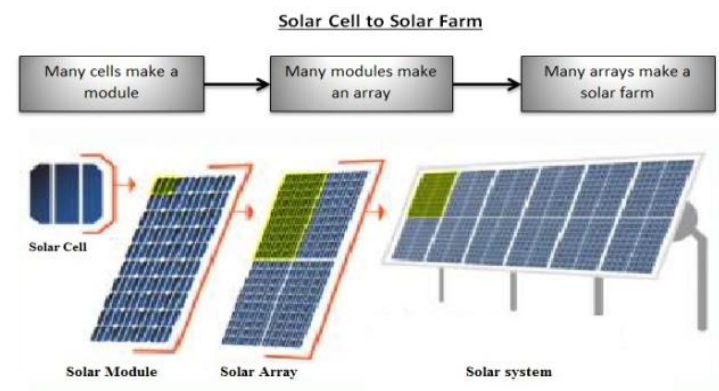

Figure 1(b). Solar cell, module and solar array

Modeling of solar PV Cell

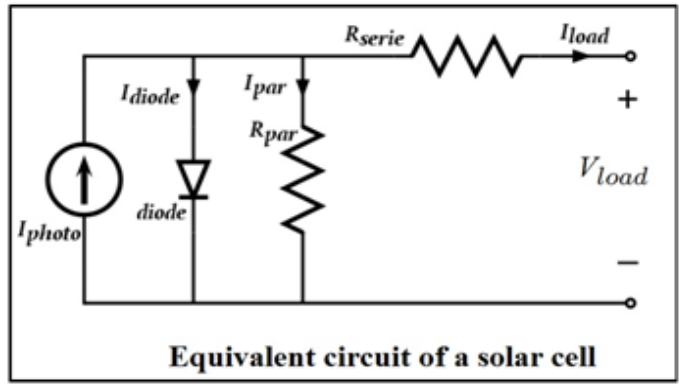

Figure1(c). Equivalent circuit of PV cell

From the above figure-1(c)[12],

$$
\begin{aligned}
& I_{\text {photo }}=I_{\text {diode }}+I_{\text {par }}+I_{\text {load }} \\
& I_{\text {load }}=I_{\text {photo }}-I_{\text {diode }}-I_{\text {par }} \\
& =I_{\text {photo }}-I_{\text {diode }}-\frac{R_{\text {serie }} I_{\text {load }}+V_{\text {load }}}{R_{\text {par }}} \\
& =I_{\text {photo }}-I_{\text {sat }}\left[\exp \left(\frac{q\left(R_{\text {serie }} I_{\text {load }}+V_{\text {load }}\right)}{k_{B} T}\right)-1\right] \\
& -\frac{R_{\text {serie }} I_{\text {load }}+V_{\text {load }}}{R_{\text {par }}} \\
& --(1)
\end{aligned}
$$

Equation-1 is the mathematical representation of practical PV cell model.

where, $\mathrm{I}_{\text {load }}$ and $\mathrm{V}_{\text {load }}$ are load current and load voltage, $\mathrm{I}_{\text {photo }}$ is photo-generated current[A], $\mathrm{I}_{\text {diode }}$ is diode current, $\mathrm{I}_{\mathrm{par}}$

is parallel loss current, $\mathrm{R}_{\mathrm{par}}$ is parallel resistance[ $\left.\Omega\right]$ and $R_{\text {serie }}$ is series resistance[ $\left.\Omega\right]$. $I_{\text {sat }}$ is the constant saturation current of the diode, $\mathrm{k}_{\mathrm{B}} \approx 1.38 \times 10^{-23} \mathrm{JK}^{-1}$ (Boltzmann's constant), charge of the electron $\mathrm{q} \approx 1.60 \times 10^{-19}$ Cand $\mathrm{T}$ is temperature measured at the $\mathrm{p}-\mathrm{n}$ junction.

\section{Modeling of Solar PV Array}

The figure-2 shows the solar PV array composed of Ns (no. of series modules) and $\mathrm{N}_{\mathrm{P}}$ (no. of parallel modules).

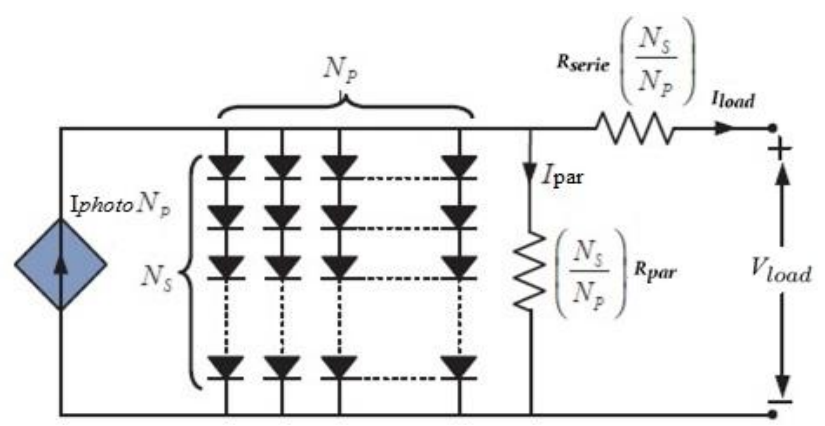

Figure 2. PV Array composed of $N_{S} \times N_{P}$ modules

$$
\begin{gathered}
I_{\text {load }}=I_{\text {photo }}-I_{\text {sat }}\left[\exp \left(\frac{q\left(R_{\text {serie }} I_{\text {load }}+V_{\text {load }}\right)}{N_{s} k_{B} T}\right)-1\right] \\
-\frac{R_{\text {serie }} I_{\text {load }}+V_{\text {load }}}{R_{\text {par }}}
\end{gathered}
$$

Equation-2 is the mathematical representation of Ns cells in module connected in series in the array.

$$
\begin{aligned}
& I_{\text {load }} \\
& =I_{\text {photo }} N_{P} \\
& -I_{\text {sat }} N_{P}\left[\exp \left(\frac{q\left(R_{\text {serie }}\left(\frac{N_{S}}{N_{p}}\right) I_{\text {load }}+V_{\text {load }}\right)}{N_{s} k_{B} T}\right)-1\right] \\
& -\frac{R_{\text {serie }}\left(\frac{N_{S}}{N_{p}}\right) I_{\text {load }}+V_{\text {load }}}{R_{\text {par }}\left(\frac{N_{S}}{N_{p}}\right)}
\end{aligned}
$$

Equation-3 is the mathematical representation of PV array composed of $\mathrm{N}_{\mathrm{S}}$ (no. of series ) $a$ and $\mathrm{N}_{\mathrm{P}}$ (no. of parallel) connected PV modules [13] shown in figure-2.

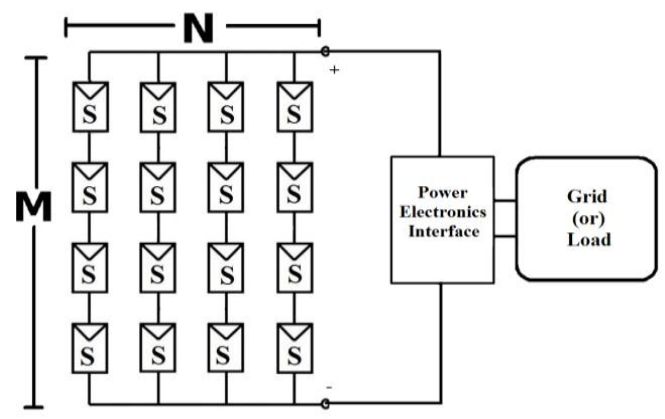

Figure 3. A Simple $4 \times 4$ size PV Plant

Figure-3 shows an simple PV plant connected to thegrid/load. In this plant, $\mathrm{M}$ is the no. of PV modules connected in one string are 4 and $\mathrm{N}$ is the no. of strings are 4. In this paper only $4 \times 4$ size PV array are analyzed by

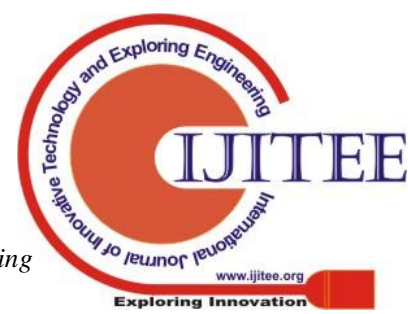


considering power loss and fill factor. The power electronics interface to the grid of the PV plant are not discussed in this work.

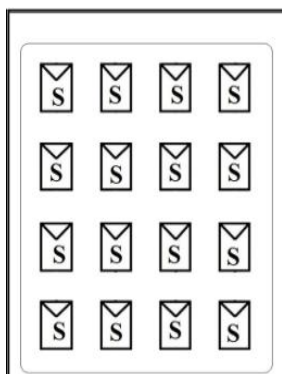

(a) Case-I

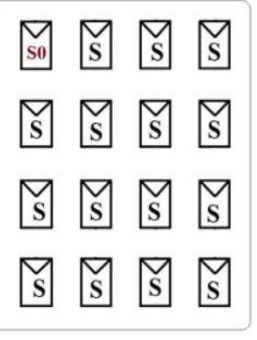

(b) Case-II

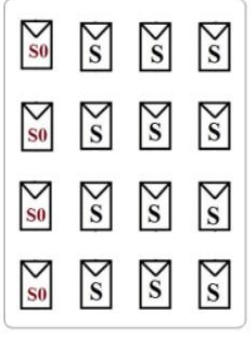

(c) Case-III

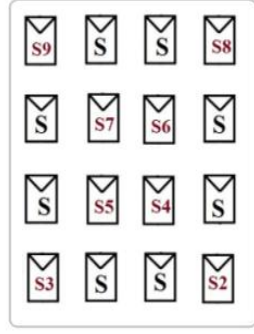

(d) Case-IV

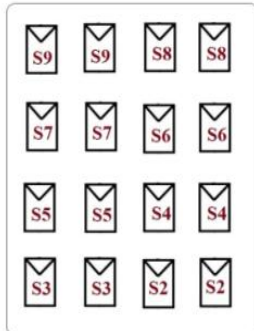

(e) Case-V

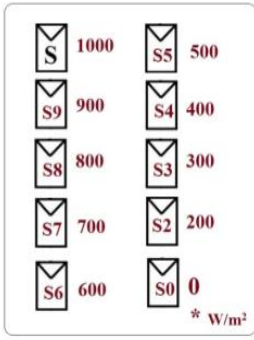

Irradiance Values

Figure 4 . Different partial shading cases of Solar PV Topologies

\subsection{Uniform irradiance and Partial Shading Cases}

This section describes the various Partial Shading Cases and irradiance levels of $4 \times 4$ size PV array with different configurations are described as follows: in this array, there are 4 strings and each string as 4 modules as shown in figure 4.

Case-I: Un-shading (Uniform irradiance) case- Under this case, all the PV modules in $4 \times 4$ size arrays of different topologies receives an uniform irradiance $1000 \mathrm{~W} / \mathrm{m}^{2}$ as shown in figure 4(a).

Case-II: One module full shading case- Under this case, the irradiance level of first PV module in first string of the array configurations receives $0 \mathrm{~W} / \mathrm{m}^{2}$ and remaining all modules are receives same irradiance $1000 \mathrm{~W} / \mathrm{m}^{2}$ as shown in figure 4(b).

Case-III: One string full shading case- Under this shading case, all modules in the first string are fully shaded with an irradiance $0 \mathrm{~W} / \mathrm{m}^{2}$, remaining all modules receives an irradiance $1000 \mathrm{~W} / \mathrm{m}^{2}$ as shown in figure $4(\mathrm{c})$.

Case-IV:Zig-zag type partial shading case- Under this partial shading case, the modules in the array topologies are receives an different irradiances as shown in figure 4(d).

Case-V: Complete PV array partial shading case- Under this case, all modules in the array receives an different irradiances as shown figure 4(e).

\section{MODELING AND SIMULATION OF SOLAR PHOTOVOLTAIC ARRAY TOPOLOGIES}

The PV system consisting of $4 \times 4$ size array modeling, simulation of different topologies are presented in this section.For modeling of solar PV topologies, LG Electronics LG215P1W PV modules as considered for PV Array. The parameters of above model and corresponding output characteristics are shown in table 1 and figure 5 respectively.

\subsection{PV model Parameters and Output Characteristics}

Table 1: Parameters of LG Electronics LG215P1W $\mathrm{PV}$ module under STC $\left(1000 \mathrm{~W} / \mathrm{m}^{2}\right.$ and $\left.25^{\circ} \mathrm{C}\right)$

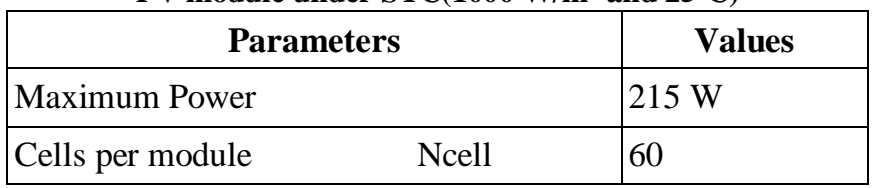

\begin{tabular}{|c|c|}
\hline Open circuit voltage & $36 \mathrm{~V}$ \\
\hline Short-circuit current & 7.99A \\
\hline Voltage at maximum power point $\mathrm{V}_{\mathrm{MP}}$ & $29.1 \mathrm{~V}$ \\
\hline Current at maximum power point $I_{M P}$ & 7.39A \\
\hline Temperature coefficient of $\mathrm{V}_{\mathrm{oc}}$ & $-0.339 \% /$ deg.C \\
\hline Temperature coefficient of & $\begin{array}{l}0.037997 \\
\% / d e g . C\end{array}$ \\
\hline Light generated current & 8.027A \\
\hline Diode saturation current & $1.225 \mathrm{e}-10$ \\
\hline Diode ideality factor & 0.93904 \\
\hline Shunt resistance & $125.259 \Omega$ \\
\hline Series resistance & $0.34933 \Omega$ \\
\hline
\end{tabular}

Output-Characteristic
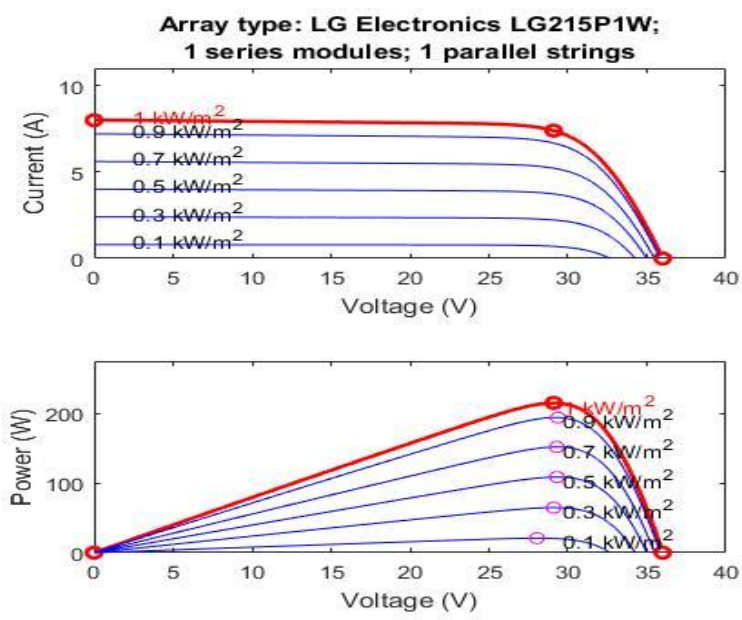

Figure 5. Output Characteristics of LG Electronics LG215P1W PV Module at different irradiances

\subsection{Solar PV Array Topologies}

The main Solar PV array configurations/topologies are,

a. Series (S) connection type

b. Parallel (P) connection type

c. Series-Parallel (S-P) connection type

d. Total-Cross-Tied (T-C-T) connection type

e. Bridge-Linked (B-L) connection type and

f. Honey-Comb (H-C) connection type

Published By:

Blue Eyes Intelligence Engineering

\& Sciences Publication 
For the simulation of above topologies, the $4 \times 4$ size array formed with $16 \mathrm{PV}$ modules and in each module total $60 \mathrm{PV}$ cells in series. Each module and string in a array are protected with anti-parallel bypass diodes and series connected blocking diodes respectively.
These $4 \times 4$ size array modules are operates at STC i.e., constant temperature of $25^{\circ} \mathrm{C}$ and different irradiance levels are shown in figure 4 . The above six solar PV topologies are shown in figure-6.

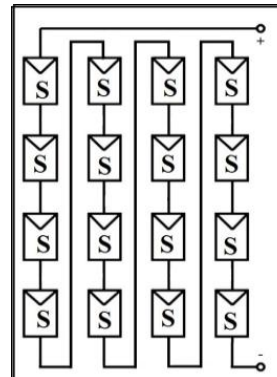

(a) Series array

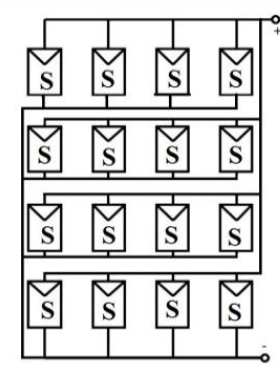

(b) Parallel array

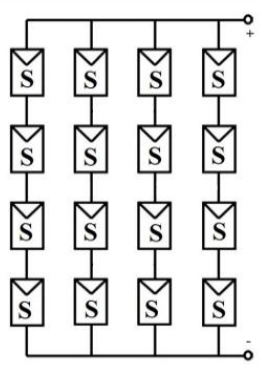

(c) S-P array

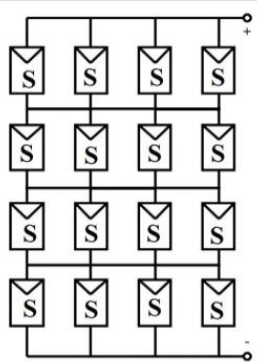

(d) TCT Array

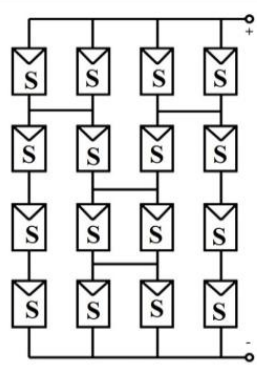

(e) HC array

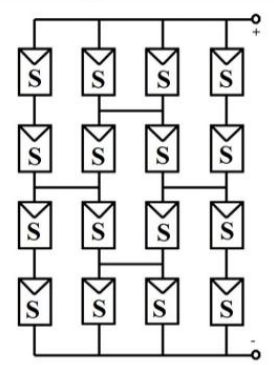

(f) BL array

Figure 6: Schematic diagrams of Solar PV Array configurations.

\subsection{Simulation of Solar PV Topologies}

In this paper, all available PV configurations/ topologies with one uniform case and four different partial shading cases are simulated in Matlab/Simulink. The simulink models of six topologies/configurations are grouped as subsystem with name Solar_PV_topologies and user for overall simulation purpose. The simulating model of different array topologies are shown in figure-7.

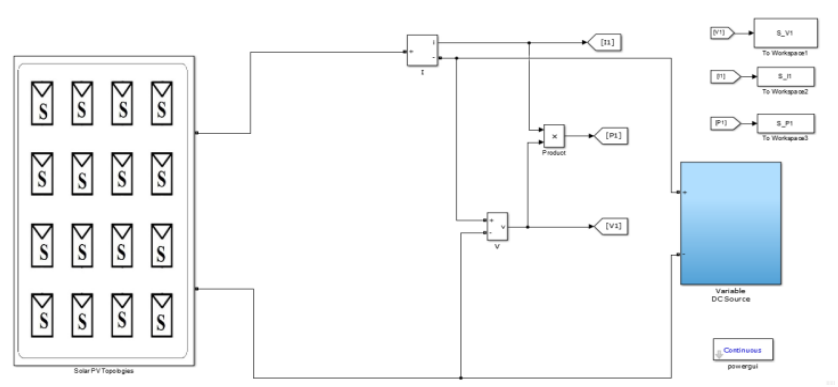

Figure 7. Simulink model of different topologies

\section{a. Series (S) topology}

The Schematic model of series topology/configuration as shown in figure.6(a).

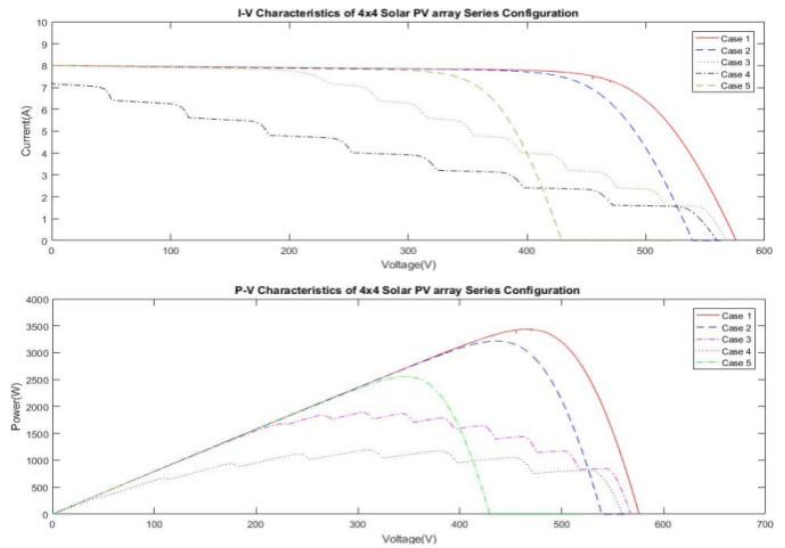

Figure 8. P-V and I-V output characteristics of $4 \times 4$ PV array series type of topology

In this topology, all modules in array are connected in series, so the total current from the array is same as pv module current and the total array voltage is sum of the individual PV module voltage. The output characteristics under shading cases $\mathrm{I}$ to $\mathrm{V}$ for series configuration are shown in figure-8.

\section{b. Parallel (P) topology}

The Schematic model for a Parallel topology as shown in figure.6(b).In this configuration, all the modules in array are connected in parallel, so that the total voltage of the array is same as pv module voltage and the total array current is sum of the individual currents of modules. The mismatching power losses are reduced by connecting anti parallel bypass diodes to each module.The output characteristics under different partial shading cases are shown in figure-9.

We notice that under partial shading cases, the characteristics of parallel configuration exhibit a single peak in presence of the bypass diodes, there is no effect on the maximum power in parallel case.

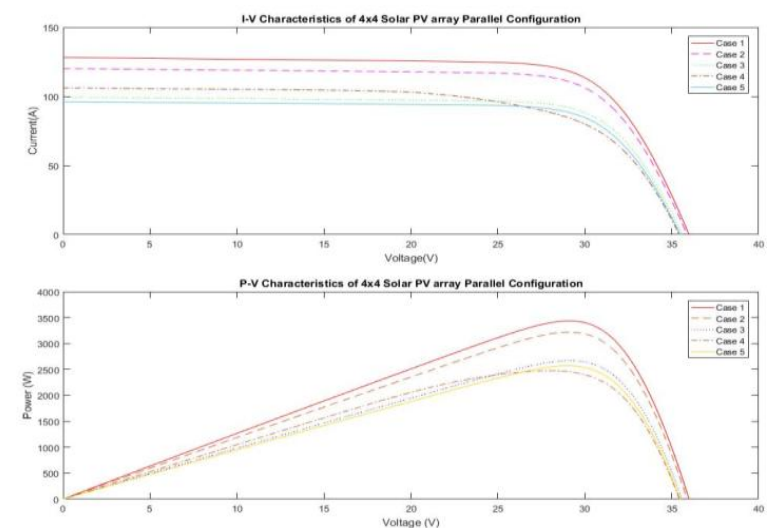

Figure 9. P-V and I-V output characteristics of $4 \times 4$ PV array Parallel type of topology

\section{c. Series-Parallel (SP) topology}

The Schematic diagram of S-P topology as shown in figure.6(c).In S-P array topology, PV strings formed by series connected modules for generating a required voltage and parallel connection of

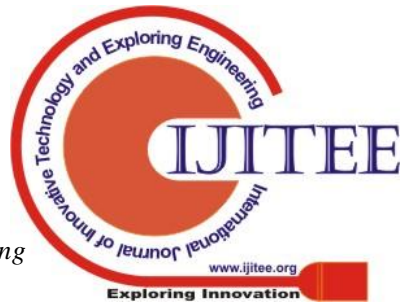


these strings for generating desired output current. The $\mathrm{P}-\mathrm{V}$ and $\mathrm{I}-\mathrm{V}$ characteristics under uniform and different shading cases for S-P configuration are shown in figure-10.
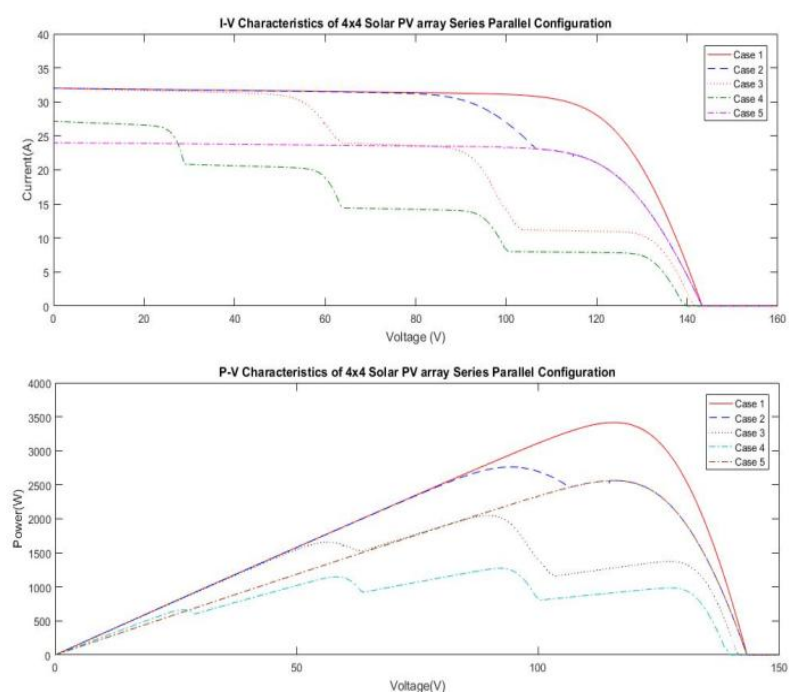

Figure 10. P-V and I-V output Characteristics of Series- Parallel type topology

\section{d. Total-Cross-Tied (TCT) topology}

The Schematic diagram of TCT topology figure 6(d). In this configuration, the open-circuit voltage of each PV module is equal to voltage across modules in each row and the total output voltage of array is the sum of voltages across all the modules in a rows. The total array current is sum of the currents of all modules in a row.The output characteristics under uniform and various shading cases shown in figure-11.
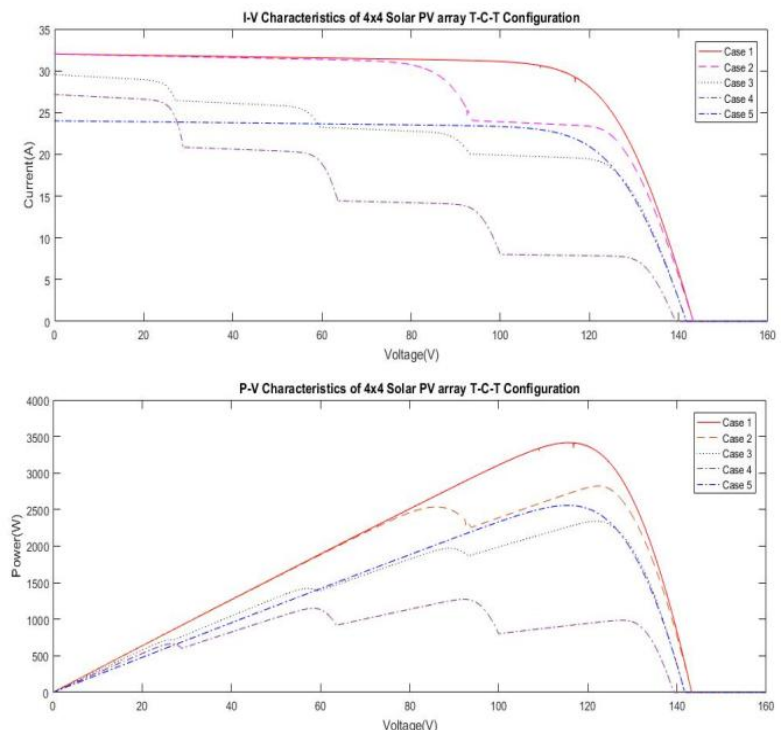

Figure 11. Output characteristics of 4 x 4 PV array Total-Cross-Tied type topology

\section{e. Bridge-Linked (BL) topology}

The Schematic diagram of BL topology figure 6(e).In this configuration, all PV modules connected in bridge rectifier type architecture for reducing the more mismatching power losses in Series and S-P type of topologies. The output characteristics under different shading cases are shown in figure-12.

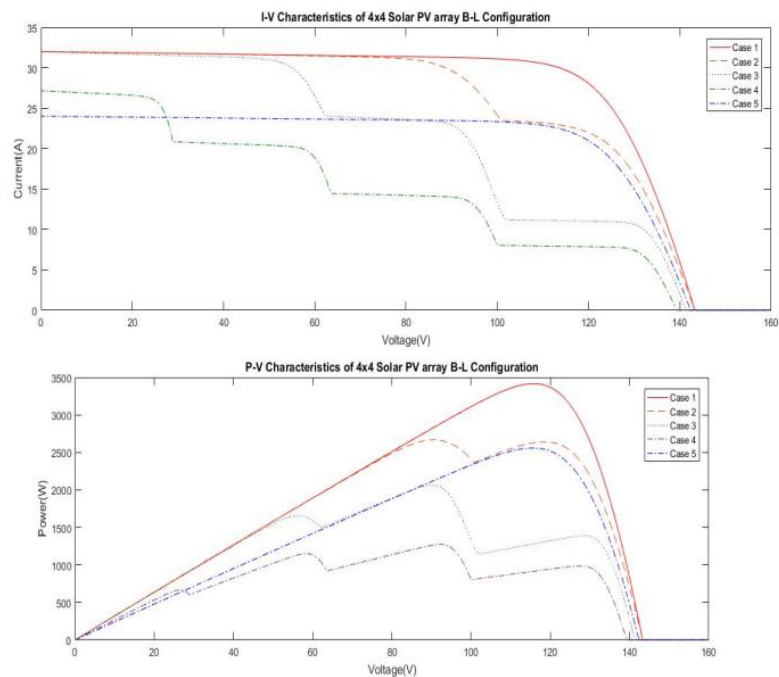

Figure 12. Output characteristics of $4 \times 4$ PV array B-L type topology

\section{f. Honey-Comb (HC) topology}

The Schematic diagram of $\mathrm{HC}$ topology as shown in figure6(f).The demerits of series and S-P array topologies can also overcome by this H-C type of configuration. In this type, all modules in array connected in the form of hexagon shape of the honey comb architecture. The output characteristics under uniform and various shading cases are shown in figure-13.
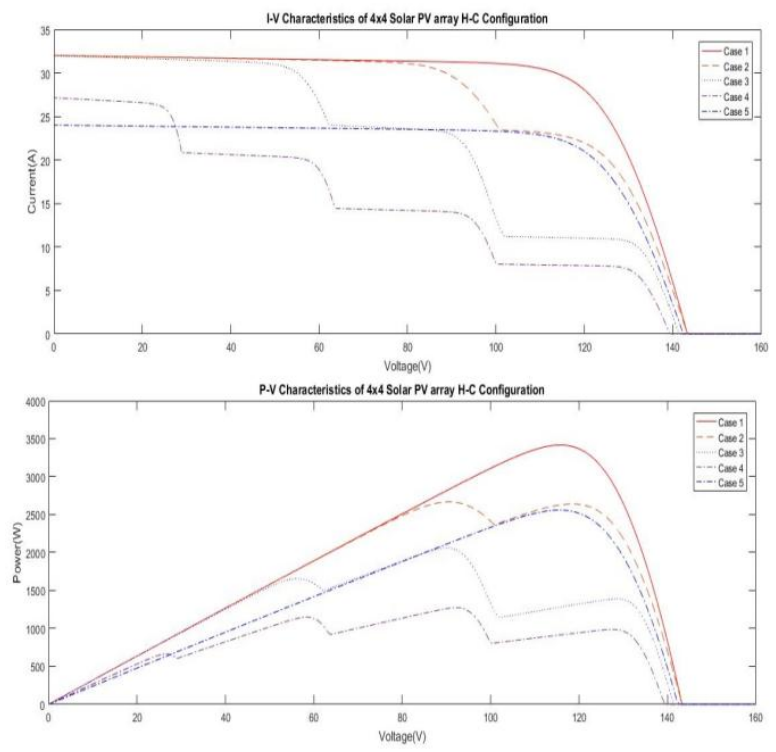

Figure 13. Output characteristics of $4 \times 4$ PV array H-C type topology

The simulation results of different type of topologies under uniform and partial shading cases for a 16 modules PV array topologies are summarizes in the table- 2 .

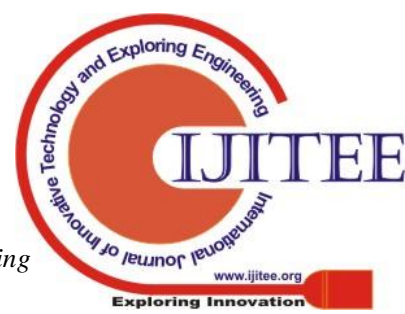




\section{PERFORMANCE AND COMPARATIVE ANALYSIS OF SOLAR PV ARRAY CONFIGURATIONS UNDER PARTIAL SHADING CASES\& RESULTS}

This section describes the performance and comparative analysis of Series, Parallel, Series-Parallel, Total-CrossTied, Bridge-Link and Honey-Comb type of topologies for $4 \times 4$ size PV arrays under uniform irradiance of $1000 \mathrm{~W} / \mathrm{m}^{2}$ and different partial shading cases (II to V). From this analysis, best topology with highest performance under different irradiance levels are selected and recommended for the design of standalone/ grid connected solar PV system. The mismatching power losses and fill-factor (FF) are considered for the performance analysis of different array topologies.

The mismatching power loss and fill-factor of the solar $\mathrm{PV}$ system is given by,

$$
\begin{aligned}
& \text { Power loss, } \Delta P_{L}(\%)=\frac{P_{M P U}-P_{M P S}}{P_{M P U}} \times 100 \\
& \text { Fill Factor, } F F=\frac{V_{M P P} \cdot I_{M P P}}{V_{O C} \cdot I_{S C}}
\end{aligned}
$$

Where $\mathrm{P}_{\mathrm{MPU}}$ is the maximum generatedpower under uniform irradiance of $1000 \mathrm{~W} / \mathrm{m}^{2}$ and $\mathrm{P}_{\mathrm{MPS}}$ is the maximum generated power under different partial shading cases. The simulation values $\mathrm{V}_{\mathrm{mps}}, \mathrm{I}_{\mathrm{mps}}, \mathrm{V}_{\mathrm{oc}}, \mathrm{I}_{\mathrm{sc}}, \mathrm{P}_{\mathrm{mps}}, \mathrm{P}_{\mathrm{mpu}}$ and also calculate the mismatch power loss and fill-factors from the equations 4 and 5 respectively are tabulated in table 2 .

From the simulation output results, the comparative analysis of six array topologies under five shading cases are discussed and case results are tabulated in table 2 .

Table 2 : Power losses analysis of a $4 \times 4$ size solar PV

\begin{tabular}{|c|c|c|c|c|c|c|c|}
\hline \multicolumn{8}{|c|}{ Case-I : Uniform irradiance of $1000 \mathrm{~W} / \mathrm{m}^{2}$} \\
\hline $\begin{array}{l}\text { Topol } \\
\text { ogy }\end{array}$ & $\begin{array}{l}\mathbf{P}_{\text {MPU }} \\
(\mathbf{w})\end{array}$ & $\begin{array}{l}\mathbf{V}_{\text {MP }} \\
(\mathbf{V})\end{array}$ & $\begin{array}{l}\mathbf{I}_{\mathbf{M P}} \\
(\mathbf{A})\end{array}$ & $\begin{array}{l}\mathbf{V}_{\text {OC }} \\
(V)\end{array}$ & $\mathbf{I}_{\mathbf{S C}}(\mathbf{A})$ & $\begin{array}{l}\Delta \mathbf{P}_{\mathbf{L}} \\
(\%)\end{array}$ & FF \\
\hline $\mathrm{S}$ & 3437 & 465.5 & 7.38 & 574.6 & 8.0 & 0 & 0.747 \\
\hline $\mathrm{P}$ & 3437 & 29.09 & 118.2 & 35.86 & 128 & 0 & 0.749 \\
\hline SP & 3416 & 115.7 & 29.52 & 142.8 & 32.01 & 0 & 0.747 \\
\hline TCT & 3416 & 115.7 & 29.52 & 142.8 & 32.01 & 0 & 0.747 \\
\hline BL & 3416 & 115.7 & 29.52 & 142.8 & 32.01 & 0 & 0.747 \\
\hline $\mathrm{HC}$ & 3416 & 115.7 & 29.52 & 143.1 & 32.01 & 0 & 0.745 \\
\hline
\end{tabular}
array topologies under different shading cases

Different Partial Shading Conditions

\begin{tabular}{|l|l|l|l|l|l|l|l|}
\hline $\begin{array}{l}\text { Topol } \\
\text { ogy }\end{array}$ & $\begin{array}{l}\mathbf{P}_{\text {MPS }} \\
(\mathbf{w})\end{array}$ & $\begin{array}{l}\mathbf{V}_{\text {MPS }} \\
(\mathbf{V})\end{array}$ & $\begin{array}{l}\mathbf{I}_{\text {MPS }} \\
(\mathbf{A})\end{array}$ & $\begin{array}{l}\mathbf{V}_{\text {OCS }} \\
(\mathbf{V})\end{array}$ & $\begin{array}{l}\mathbf{I}_{\text {SCS }} \\
(\mathbf{A})\end{array}$ & $\begin{array}{l}\Delta \mathbf{P}_{\mathbf{L}} \\
(\%)\end{array}$ & FF \\
\hline
\end{tabular}

\begin{tabular}{|l|l|l|l|l|l|l|l|}
\hline \multicolumn{1}{|l|}{ Case-I: One module full shading in $\mathbf{1}^{\text {st }}$ string condition } \\
\hline S & 3217 & 435.8 & 7.38 & 538.8 & 8.0 & 6.40 & 0.74 \\
\hline P & 3221 & 29.09 & 110.7 & 35.75 & 120.1 & 6.28 & 0.75 \\
\hline SP & 2762 & 94.58 & 29.29 & 142.7 & 32.1 & 19.14 & 0.60 \\
\hline TCT & $\mathbf{2 8 2 3}$ & $\mathbf{1 2 2 . 3}$ & $\mathbf{2 3 . 0 8}$ & $\mathbf{1 4 2 . 7}$ & $\mathbf{3 1 . 9 6}$ & $\mathbf{1 7 . 3 6}$ & $\mathbf{0 . 6 1}$ \\
\hline BL & 2667 & 90.54 & 29.46 & 142.8 & 32.01 & 21.92 & 0.58 \\
\hline HC & 2693 & 120.7 & 22.31 & 142.8 & 32.01 & 21.16 & 0.59 \\
\hline \multicolumn{7}{|c|}{ Case III : 1 } & string fully shading condition \\
\hline S & 2557 & 346.5 & 7.38 & 428.3 & 8.0 & 25.60 & 0.74 \\
\hline P & 2571 & 29.02 & 88.6 & 35.39 & 96.31 & 25.19 & 0.75 \\
\hline
\end{tabular}

\begin{tabular}{|l|l|l|l|l|l|l|l|}
\hline SP & 2562 & 115.7 & 22.14 & 143 & 24.01 & 25.14 & 0.74 \\
\hline TCT & $\mathbf{2 5 5 7}$ & $\mathbf{1 1 5 . 5}$ & $\mathbf{2 2 . 1 5}$ & $\mathbf{1 4 1 . 6}$ & $\mathbf{2 4 . 0 1}$ & $\mathbf{2 5 . 0 8}$ & $\mathbf{0 . 7 5}$ \\
\hline BL & 2559 & 115.5 & 22.15 & 141.8 & 24.0 & 25.08 & 0.75 \\
\hline HC & 2557 & 115.5 & 22.15 & 142.2 & 24.08 & 25.08 & 0.74 \\
\hline \multicolumn{7}{|c|}{ Case IV : Zig-Zag Type partial shading condition } \\
\hline S & 1889 & 304.1 & 6.21 & 566.3 & 7.99 & 45.03 & 0.41 \\
\hline P & 2970 & 29.16 & 91.58 & 35.53 & 99.29 & 13.58 & 0.75 \\
\hline SP & 2048 & 89.75 & 22.82 & 141 & 32.11 & 40.04 & 0.45 \\
\hline TCT & $\mathbf{2 3 4 3}$ & $\mathbf{1 2 1 . 9}$ & $\mathbf{1 9 . 2 3}$ & $\mathbf{1 4 2 . 5}$ & $\mathbf{2 9 . 5 3}$ & $\mathbf{3 1 . 4 1}$ & $\mathbf{0 . 5 5}$ \\
\hline BL & 2064 & 90.04 & 22.92 & 143.3 & 31.96 & 39.57 & 0.45 \\
\hline HC & 2180 & 87.98 & 24.77 & 141.6 & 31.96 & 36.18 & 0.48 \\
\hline Case V $\mathbf{: C o m p l e t e ~ P V ~ a r r a y ~ p a r t i a l ~ s h a d i n g ~ c o n d i t i o n ~}$ \\
\hline S & 1196 & 309.4 & 3.86 & 557.8 & 7.22 & 65.20 & 0.29 \\
\hline P & 2476 & 27.96 & 88.53 & 35.32 & 106.7 & 27.96 & 0.65 \\
\hline SP & 1273 & 92.16 & 13.81 & 139.5 & 27.28 & 62.73 & 0.33 \\
\hline TCT & $\mathbf{1 2 7 4}$ & $\mathbf{9 2 . 2}$ & $\mathbf{1 3 . 8 1}$ & $\mathbf{1 3 9 . 2}$ & $\mathbf{2 7 . 2 8}$ & $\mathbf{6 2 . 7 0}$ & $\mathbf{0 . 3 3}$ \\
\hline BL & 1273 & 92.16 & 13.82 & 139.4 & 27.15 & 62.73 & 0.32 \\
\hline HC & 1273 & 92.16 & 13.82 & 139.4 & 27.14 & 62.73 & 0.33 \\
\hline
\end{tabular}

From the comparative analysis, it can be concluded that:

$>$ In all cases, the Parallel configuration produces highest maximum power, least mismatching power losses and high value of fill-factor and also high currents and low voltages are generated. Due to this reason, the parallel topology is not suitable for many PV system applications. In this paper for the performance analysis, only S, SP, TCT, BL and HC type of PV array topologies are considered.

> In Case-I: Uniform irradiance of $1000 \mathrm{~W} / \mathrm{m}^{2}$, all PV array configurations generates approximately same maximum power, there is no mismatching power losses and the fill-factor approximately 0.75 .

$>$ In Case-II: One module in $1^{\text {st }}$ string fully shaded at an irradiance $0 \mathrm{~W} / \mathrm{m}^{2}$ : The $\mathrm{S}, \mathrm{P}$ configurations has produces approximately same maximum power and also same relative power losses. Compare to $\mathrm{SP}, \mathrm{BL}, \mathrm{HC}$ configurations T-C-T topology has less power losses and high fill-factor.

$>$ In Case-III: $1^{\text {st }}$ string fully shaded condition, in this case the TCT configuration produces maximum power and less relative power losses. So in case 3 , the TCT has best performance.

> In Case-IV: Under Zig-zag type partial shading condition, compare to S,SP,BL,HC configurations the TCT topology generates maximum power and less mismatching power losses, high fill-factor.

In Case-V, Under all PV modules are completely partial shading condition, the SP,TCT,BL,HC type of configurations generates same maximum power and less mismatching losses.

When entire PV array are partially shaded, in all cases the TCT configuration provides the best performance in terms of highest maximum generating power and least relative power losses, it is usually followed by the HC

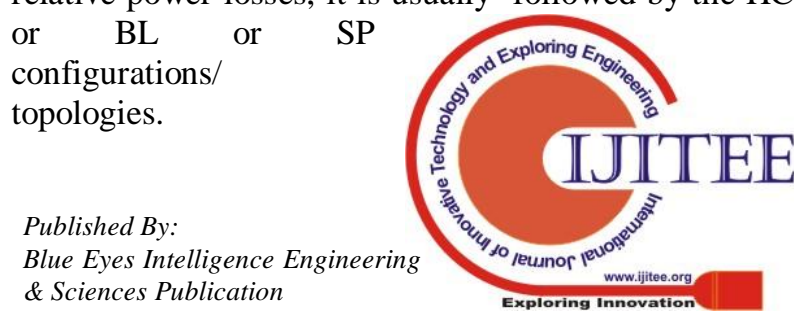




\section{CONCLUSIONS}

In this paper, the comparative and performance analysis of available different PV array topologies Series(S), SeriesParallel(SP), Parallel(P), Total-Cross-Tied(TCT), Bridge Linked (BL), Honey-Comb(HC) types are presented. This research article has investigated the performance of available six PV array configurations under uniform and various shading cases such as; one module shading, one string shading, zig-zag partial shading, complete array partial shading cases and the output characteristics of above topologiesare analyzed. The comparative and performance analysis of arrays are determined by considering mismatching power losses and fill factors. From this analysis, it is observed that the parallel array topology generates highest maximum power due to its high currents and low voltage, this parallel type topology is not suitable for many PV applications so that other PV topologies are considered for performance analysis. Under the partial shading cases II to $\mathrm{V}$, compare to $\mathrm{S}, \mathrm{SP}, \mathrm{HC}, \mathrm{BL}$ configurations the T-C-T topology has the highest output power and least mismatching power losses as followed by the $\mathrm{BL}$ or $\mathrm{HC}$ or SP topologies.

\section{REFERENCES}

1. Meral et.al,. "A review of the factors affecting operation and efficiency of photovoltaic based electricity generation systems." Renewable and Sustainable Energy Reviews (2011): 2176-2184.

2. Nguyen, Dzung D., and Brad Lehman. "Modeling and simulation of solar PV arrays under changing illumination conditions.", COMPEL'06. IEEE Workshops on. IEEE, 2006.

3. Fesharaki, V. Jafari, et al. "The effect of temperature on photovoltaic cell efficiency."1stInternational Conference on Emerging Trends in Energy Conservation-ETEC, Iran. 2011.

4. Petrone, Giovanni, and C. A. Ramos-Paja. "Modeling of photovoltaic fields in mismatched conditions for energy yield evaluations." Electric Power Systems Research 81.4 (2011).

5. Mastromauro, et.al,. "Control issues in single-stage photovoltaic systems: MPPT, current and voltage control." IEEE Transactions on Industrial Informatics 8.2 (2012): 241254.

6. Wang, et.al,."Analyticalmodelling of partial shading and different orientation of pv modules." IET Renewables 4.3 (2010).

7. Kaushikaet. al,."Energy yield simulations of interconnected solar PV arrays." IEEE Trans. on Energy Conversion 18.1 (2003).

8. Salameh, Ziyad M., and FouadDagher. "The effect of electrical array reconfiguration on the performance of a PVpowered volumetric water pump." IEEE (1990): 653-658.

9. Woyte, Achimet. al,. "Partial shadowing of photovoltaic arrays with different system configurations: literature review and field test results." Solar energy 74.3 (2003): 217-233.

10. Satpathy, PriyaRanjan, Sasmita Jena, Bibekananda Jena, and Renu Sharma. "Comparative study of interconnection schemes of modules in solar PV array network." In Circuit, Power and Computing Technologies (ICCPCT), IEEE, 2017.

11. Gautam, Nalin K., and N. D. Kaushika. "Reliability evaluation of solar photovoltaic arrays." Solar Energy 72.2 (2002): 129141.

12. Suthar, M., et al., 2013. Comparison of mathematical models of photo-voltaic (PV) module and effect of various parameters on its performance. In: IEEE Int. Conf. Energy Efficient Technologies for Sustainability. pp. 1354-1359
13. Villalva, M.G., et al,, "Comprehensive approach to modeling and simulation of photovoltaic arrays". IEEE Trans. Power Electron., 2009.

14. PriyaRanjanSatpathyet. al,." Topology Alteration for Output Power Maximization in PV Arrays under Partial Shading", IEEE Int. Conf. smart-City Energy Security and Power (ICSESP-2018).

15. RanjanSatpathyet. al,."Comparative Study of Interconnection Schemes of Modules in Solar PV Array Network", ICCPCT, 2017. 